ISSN: $2338-4794$

Vol.6. No. 2 Mei-Agustus 2018

\title{
PENGARUH KUALITAS LAYANAN DAN KOMPETENSI KARYAWAN TERHADAP KEPUASAN NASABAH ( Studi Kasus pada PT. Bank Tabungan Negara KCP Cibubur )
}

\author{
Eko Wahyudi ${ }^{1)}$ \\ 1) Mahasiswa Program Studi Manajemen FE UNKRIS \\ Imam Wibowo ${ }^{2)}$ \\ 2) Dosen Program Studi Manajemen FE UNKRIS \\ Alamat: Kampus UNKRIS, Jatiwaringin Jakarta Timur \\ Email: wibowoimam253@gmail.com
}

\begin{abstract}
This research is based on competition for the struggle of customers in the banking world, thus demanding banking companies to compete to attract customers by constantly improving the quality of service and competence of employees who are considered as representative banking companies as a form of satisfaction fulfillment to its customers. The purpose of this study to determine how the influence of Service Quality and Employee Competence to customer satisfaction PT. Bank Tabungan Negara (Bank BTN), either partially or simultaneously. This research used qualitative method with descriptive research type. Sampling is used with non probability method of incidental sampling. The result of the simultaneous research on the quality of service and the competence of the employees is significant to customer satisfaction, partially the quality of service and employee competency also have a significant influence on customer satisfaction. Thus, banks should continue to improve the quality of service and employee competence in order to achieve customer satisfaction and attention to other aspects that add value from customer satisfaction.
\end{abstract}

Keywords: Service Quality, Employee Competence, Customer Satisfaction

\section{PENDAHULUAN}

Kepuasan nasabah adalah sebuah gol atau pencapaian utama dari Bisnis Jasa Perbankan, dimana ketika nasabah puas dengan apa yang diberikan oleh Bank, baik dari sisi produk, pelayanan dan bentuk Gimick lain yang bisa di berikan, mereka akan merasa nyaman dan akhirnya kembali lagi dan beranggapan bahwa bank tersebut layak dan mampu untuk menyimpan uangnya. Itulah tujuan dari sebuah strategi pemasaran bisnis jasa perbankan, Menurut Kotler (2002) "Kepuasan konsumen adalah perasaan senang atau kecewa seseorang yang berasal dari perbandingan antara kesannya terhadap kinerja (atau hasil) suatu produk yang diharapkannya", sedangkan menurut Lovelock dan Witrz (2011) kepuasan merupakan "keputusan sikap berdasarkan pengalaman yang didapatkan". Melihat teori tersebut yang kaitanya dengan kondisi saat ini sangat jelas terlihat bahwa kepuasan nasabah dipengaruhi oleh baik atau tidaknya memori seseorang terhadap pengalamanya atas penggunaan sebuah produk atau jasa yang ditawarkan atau diberikan oleh perusahaan, sehingga keinginan nasabah terpuaskan atau tidak akan dinilai dari sistem pelayananya yang di bandingkan dengan ekspetasi dari nasabah. Dengan demikian, saat ini seluruh perusahaan jasa perbankan berlomba-lomba untuk memuaskan nasabahnya, yang tentunya bertujuan merebut sebanyak-banyaknya nasabah, baik melalui penawaran kualitas layanan terbaik, perekrutan SDM yang kompeten dalam bidangnya, pembaruan sistem informasi, dan jenis-jenis produk jasa yang ditawarkan serta kemudahan- 
kemudahan untuk memanjakan nasabahnya.

Pentingnya kepuasan nasabah bagi perusahaan menurut Lovelock dan Wright (2005) "bahwa kepuasan pelanggan memberikan banyak sekali manfaat bagi perusahaan, sehingga mempertahankan kepuasan pelanggan dalam jangka panjang akan lebih menguntungkan di banding jika harus terus menerus menarik dan membina nasabah baru untuk menggantikan nasabah yang pergi", sehingga dapat di artikan bahwa ketika konsumen puas dengan produk, pelayanan dan lainya maka secara manusiawi seorang nasabah akan loyal terhadap perusahaan bahkan dapat pula menjadi agen atau pemasar yang tidak secara langsung akan merekomedasikan produk bank kepada masyarakat sekitar, begitupun kepuasan sangat penting bagi konsumen di karenakan kepuasan sangat erat kaitanya dengan kepercayaan (truth), sehingga kualitas layanan dan kompetensi karyawan sebuah bank akan menjadi faktor utama penentu apakah bank tersebut mampu untuk di percaya atas uang atau investasi yang tanamkannya. Nasabah yang sudah percaya dengan sebuah bank, dia akan terus menjadi nasabah setia dari sebuah bank tersebut. Ada beberapa faktor yang menjadi parameter kepuasan pelanggan yang harus diperhatikan oleh perusahaan, menurut Irawan (2008), faktor-faktor yang pendorong kepuasan pelanggan adalah kualitas produk, harga, service quality, emotional factor, serta biaya dan kemudahan.

Penelitian yang dilakukan oleh Tombokan, et. al (2015), dalam hasil penelitianya menyebutkan kualitas pelayanan dan citra merek memiliki pengaruh yang signifikan terhadap kepuasan konsumen. Penelitian lain yang dilakukan oleh Ridwinsyah (2017) dalam penelitianya mendapatkan menyebutkan hasil kompetensi dalam indikator pengetahuan, keterampilan dan sikap secara bersama-sama berpengaruh positif dan signifikan terhadap kepuasan nasabah, dan juga penelitian yang dilakukan oleh Long, et. al (2014), mendapatkan hasil bahwa terdapat hubungan yang signifikan diantara kedua variable kompetensi dosen dan kepuasan siswa

$\begin{array}{ccr}\text { Kualitas layanan menuru } \\ \text { pendapat Goetsh dan Davis } & (2002) \\ \text { didesksirpsikan sebagai "suatu kondis }\end{array}$ dinamis yang berhubungan dengan produk, jasa, manusia, alam dan lingkungan yang memenuhi atau melebihi harapan", sedangkan pendapat Kotler (2005) Kualitas Layanan sebagai "model yang menggambarkan kondisi pelanggan dalam membentuk harapan akan layanan dari pengalaman masa lalu, promosi dari mulut ke mulut dan iklan dengan membandingkan pelayanan yang mereka harapkan dengan apa yang mereka terima", sehingga dapat dikatakan bahwa kualitas layanan merupakan gambaran dari perusahaan bagaimana melayani nasabah dengan sebaikbaiknya, sehingga akan tercipta suatu hubungan yang baik antara perusahaan dengan nasabah. Karena pelayanan yang baik adalah cerminan dari perusahaan yang matang dalam menjalankan operasinya. Penyertaan nilai-nilai kualitas layanan menjadi standar pelayanan nasabah, baik bertemu langsung maupun tidak, baik dalam keadaan tertekan dan kondisi yang tidak memungkinkan, di harapkan dapat memberikan pelayanan yang maksimal.

Kompetensi karyawan menurut Wibowo (2007) Sebagai "suatu kemampuan untuk melaksanakan atau melakukan suatu pekerjaan atau tugas yang dilandasi atas keterampilan dan pengetahuan serta didukung oleh sikap kerja yang dituntut oleh pekerjaan tersebut". Lain dengan Mangkunegara (2005) mengemukakan bahwa "kompetensi merupakan faktor mendasar 
yang dimiliki seseorang yang mempunyai kemampuan lebih, yang membuatnya berbeda dengan seseorang yang mempunyai kemampuan rata-rata atau biasa saja". Sehingga Kompetensi merupakan syarat dari karyawan yang baik, sehingga kompetensi karyawan dapat di anggap sebagai gambaran seseorang atas kemampuannya bertanggung jawab atas materi yang dia emban. Atas kemampuan tersebut yang kaitanya dengan pekerjaan, kompetensi haruslah dimilki tiap individu, untuk menjadi sesorang yang profesional, dan berintegiras dalam menjalankan tugasnya sebagai karyawan agar dapat mewakili perusahaan untuk nasabah.

Sehingga ditengah persaingan jasa perbankan yang ketat saat ini, untuk menghadapi gempuran perusahan perbankan lainya, serta untuk untuk tetap mempertahankan eksistensi dalam usahanya, perusahaan perbankan harus terus berjuang keras untuk dapat mempertahankan dan merebut hati masyarakat dalam upaya mensejajarkan diri dengan perusahaan perbankkan lainya, tentu dengan memperbaiki kualitas pelayanan, kualitas produk, peningkatan sumber daya manusia dan penggunaan teknologi terbaik. Oleh karena itu hampir seluruh perusahaan jasa perbankan ingin dipersepsikan sebagai perusahaan yang memiliki reputasi dan citra tersebut. Usaha perbaikan diatas merupakan upaya di gunakan oleh perusahaan jasa perbankan untuk mendapatkan pengakuan dibenak nasabahnya. Pengambilan stategi pemasaran tersebut di landasi bahwa statement bahwa reputasi yang baik adalah modal utama untuk memperoleh kepercayaan dari nasabah yang merupakan aset penting dalam dunia perbankkan.

PT.Bank Tabungan Negara (Persero).Tbk adalah Bank BUMN yang berdiri sejak tahun 1897 (pada saat itu masih bernama Postpaarbank), telah berpengalaman melayani masyarakat Indonesia dengan produk unggulanya yaitu KPR, secara konsisten manjalankan komitmen tersebut menjadi Bank yang terdepan dalam pembiayaan perumahan untuk masyarakat Indonesia, sehingga bermacam Produk KPR yang bervariasi seperti, KPR Subsidi, KPR Platinum, KGU Second Hand, Kredit Bangun Rumah, Ruko dan Kredit Agunan Rumah, serta seperti Bank konvensional lainya, Bank BTN Juga memiliki Produk Tabungan yang berbunga kompetitif seperti Tabungan Batara Prima, Tabungan Batara Junior, dan Batara Juara yang sesuai dengan segmentasinya, Serta Deposito, dan Giro ditambah BTN Prioritas tentunya yang menyasar pada nasabah prioritasnya. Bank BTN Memiliki bermacam strategi dalam mempertahankan eksistesninya dalam menjadi leader pembiayaan perumahan rakyat Indonesia, tidak di pungkiri pula bank pesaing mulai menggerus pangsa pasar yang selama ini di miliki Bank BTN, sehingga sangat di butuhkan sistem pelayanan nasabah yang profesional, tentunya untuk menarik kembali minat masyarakat dan mengembalikan kepercayaan atas penggunaan produk dari Bank BTN. Menjadi bukti, bahwa pada tahun 2015 , Bank BTN yang berkomitmen teeguh untuk melayani segala kebutuhan nasabah dan masyarakat luas dengan kualitas layanan prima, sukses mengantar

Bank BTN meraih predikat "golden" katagori Priority Banking melalui produk BTN Prioritas, dalam ajang "service quality award 2015" yang digagas oleh majalah service excellent bekerja sama dengan carre-center for customer satisfaction \& loyalty ( carreCCSL) yang berbasis pelayanan. Bahkan pada tahun 2017 bank BTN berhasil meraih lima penghargaan sekaligus dalam ajang Indonesia Banking Award (IBA) 2017, penghargaan yang di terima bank BTN antara lain, katagori the most 
efficient Bank, The Best Bank in Digital Services, The Best bank in Retail Banking Services, The Best Best Sharia Business Unit, dan Best Bank in Productivity. Fenomena lain adalah bahwa selama menjalankan operasinya, peneliti mengamati keseharian dari Bank BTN Cibubur dalam melayani nasabahnya, dalam kantor tersebut sangat ramai dan sehingga akan menuntut banyak sekali Layanan yang prima dari karyawan Bank BTN, Kompetensi karyawan akan di tuntut sebaik-baiknya ketika nasabah berdada pada lingkungan kerja yang Crowded, Ini menjadi sebuah fenomena dimana seseorang ataupun sebuah instansi lembaga survey akan sangat tertarik kepada sebuah perusahaan dilihat performanya dalam menawarkan services ataupun kinerja karyawan yang baik. Dengan begitu akan dapat menimbulkan persfektif yang baik di benak masyarakat, baik dalam hal reputasi dan hal lainya.

\section{LANDASAN TEORI}

\section{Kepuasan Pelanggan}

Kotler dan Keller (2007) kepuasan diartikan sebagai "perasaan senang atau kecewa yang muncul dari diri seseorang setelah membandingkan kinerja atau hasil produk yang dipikirkan terhadap kinerja yang diharapkan". Yang berarti sebuah perbandingan antara kinerja dan harapan sebuah produk sehingga perasaanya akan terpengaruhi olehnya. Yang ditegaskan di buku lain, Kotler dan Armstrong (2001), "Kepuasan konsumen sebagai sejauh mana penilaian kinerja produk atau jasa memenuhi harapan pembeli". Sehingga dapat di artikan produk haruslah sebuah memiliki nilai lebih agar dapat memuhi harapan pembelinya, bila kinerja produk atau jasa lebih tinggi dari harapan pelanggan, maka pembelinya akan merasa senang dan amat puas.

Menurut Barnes (2003) "Kepuasan adalah tanggapan pelanggan atas terpenuhinya kebutuhannya". Hal itu berarti bahwa suatu bentuk penilaian berdasarkan keistimewaan dari suatu barang atau jasa ataupun barang atau jasa itu sendiri, memberikan tingkat kenyamanan yang terkait dengan pemenuhan suatu kebutuhan, termasuk pemenuhan kebutuhan atas harapan atau pemenuhan kebutuhan melebihi atau bahkan dibawah harapan pelanggan.

Zeithaml dan Bitner (2010) yang mendefinisikan kepuasan sebagai "respon konsumen akan pemenuhan kebutuhan. Dimana kepuasan merupakan penilaian atas ciri atau keistimewaan produk atau jasa dari peusahaan, yang menyediakan tingkat kesenangan konsumen berkaitan dengan pemenuhan kebutuhan konsumsi konsumen", dapat jelaskan kepuasan sebagai sebuah respon dari konsumen atas penggunaan produk dan jasa yang di bandingkan dengan ekspetasinya atas produk atau jasa tersebut.

Yamit (2005) yang

mendeskripsikan "kepuasan konsumen sebagai hasil evaluasi setelah membandingkan apa yang dirasakan dengan harapannya". Dimana dalam konsep kepuasan konsumen, terdapat dua faktor yang mempengaruhi yaitu harapan dan kinerja, sehingga ketika pembeli mengkonsumsi sebuah produk atau jasa, maka dia berharap hal itu dapat memenuhi harapanya, sejauh apa kinerja dari produk tersebut akan sangat berpengaruh terhadap kepuasan.

Tujuan perusahaan adalah memberikan kepuasan pada konsumen melalui penawaran produk yang memiliki nilai lebih, yang dharapkan dapat memberi kepuasan yang lebih bagi konsumen. Nilai produk dapat dipenuhi dengan peningkatan kegunaan produk. Inilah yang menjadi dasar bagi perusahaan untuk dapat memenuhi kebutuhan dan harapan konsumen akan barang atau jasa, sehingga tercapailah kepuasan konsumen. Penilaian kepuasan konsumen mempunyai tiga bentuk yang berbeda yaitu: a). Positive 
disconfirmation, yaitu kinerja lebih baik dari harapan. b). b. Simple confirmation, yaitu kinerja sama dengan harapan. c). Negative disconfirmation, yaitu kinerja lebih buruk dari harapan.

Pada dasarnya tujuan dari suatu bisnis adalah menciptaka rasa puas pada konsumen, Tjiptono, (2008). Terciptanya kepuasan konsumen dapat memberikan beberapa manfaat diantaranya: a). Hubungan perusahaan dengan konsumen menjadi harmonis. b). Memberikan dasar yang baik bagi pembeli ulang. c). Dapat mendorong terciptanya loyalitas konsumen. d). Membentuk rekomendasi dari mulut ke mulut (word of mouth) yang menguntungkan perusahaan.

Pengukuran kepuasan konsumen sangatlah penting untuk dilakukan, karena memberikan informasi yang bermanfaat bagi perusahaan. Menurut Hawkins dan Lonnet yang dikutip Tjiptono (2004) atribut atau indikator yang membentuk kepuasan adalah berikut: 1). Re-purchase : dalam dunia perbankan dapat diartikan sebagai untuk minat berkunjung kembali. 2). Menciptakan Word-of-Mouth: dapat dikatakah adalah keseddian nasabah untuk merekomendasikan produk maupun berita baik dari perusahaan bank terkait kepada orang lain. 3). Kesesuaian Harapan: merupakan tingkat kesesuaian antara kinerja dengan harapan yang dirasakan oleh nasabah.

\section{Kualitas Layanan}

Goetsh dan Davis (2002) mendeskripsikan kualitas layanan sebagai "suatu kondisi dinamis yang memiliki hubungan dengan jasa, produk, manusia, alam dan lingkungan yang memenuhi atau melebihi harapan", sedangkan menurut Sampara (1999) dalam Hardiyansyah (2011), mengartikan kualitas pelayanan sebagai "pelayanan yang diberikan kepada pelanggan sesuai dengan standar pelayanan yang telah dibakukan dalam rangka memberikan layanan yang baik" artinya kualitas pelayanan sebagai standar layanan itu sendiri, jika sebuah standar layanan tidak terpenuhi kemungkinan akan mengakibatkan pengaruh terhadap aspek lainya yang mengalami kontak langsung denganya.

Kotler (2000) mendeskripsikan kualitas pelayanan "sebagai totalitas dari bentuk karakteristik barang dan jasa yang menunjukkan kemampuannya untuk memuaskan kebutuhan pelanggan, baik yang terlihat jelas ataupun yang tersembunyi". Dapat diartikan bahwa kualitas pelayanan adalah usaha dari perusahaan tersebut yang kaitanya dengan memuaskan pelanggan dalam penyertaanya atas produk jasa yang dia keluarkan.

Suwithi dalam Anwar (2002) mengartikan kualitas pelayanan adalah "mutu dari pelayanan yang diberikan kepada konsumen atau pelanggan, baik pelanggan internal ataupun eksternal berdasar pada standar prosedur pelayanan". Yang dapat diartikan bahwa segala macam lapisan pelanggan haruslah mendapatkan pelayanan terbaik berdasarkan prosedur yang diberlakukan perusahaan yang menjadi standar dari layananya tanpa membedakan golongan konsumen.

Stanton (1981) dalam Alma (2013) Service are those separately identifitable, essentially intangible activities that provide want-satisfaction, and that are not necessarily tied to the sale of a productor another service. To produce a service may or may not require the use of tangible goods. However, when such use is required, there is no transfer of the title ( permanent ownership) to these tangible goods. Dapat diartikan bahwa jasa sebagai sesuatu yang diidentifikasikan secara terpisah tidak terwujud, di tawarkan untuk memenuhi kebutuhan, jasa dapat dihasilkan dengan 
menggunakan benda-benda berwujud atau tidak.

Dengan melihat teori-teori tersebut maka dapat diartikan bahwa kualitas pelayanan memiliki peran sebagai rantai pengikat dari perusahaan kepada nasabahnya, kualitas layanan diharapkan dapat memberikan kontribusi dalam menjaga hubungan itu tetap baik. Hal ini tentu saja harus dilakukan karena dengan menjaga hubungan yang baik dengan nasbah juga berarti menjaga reputasi perusahaan agar dapat terus meningkat dalam rangka proses pemberian kepuasan, proses atau sistem yang bertugas untuk memberikan atau memenuhi kebutuhan baik pelayanan dan informasi secara keseluruhan, dan merupakan perantara antara perusahaan dengan konsumen yang akan menggunakan produk perusahaan tersebut, serta memberikan keuntungan bagi kedua belah pihak. Hal ini didesain, dilaksanakan dan dikomunikasikan dengan dua tujuan utama, yaitu produktivitas oprasional dan kepuasan konsumen.

Parasuraman dalam Zeithaml, et. al. (2009) menjelaskan lima dimensi kualitan layanan, kelima dimensi yang dimaksud adalah: a). Tangibles (bukti fisik); didalamyna terdapat fasilitas fisik, perlengkapan, pegawai dan sarana komunikasi serta kendaraan operasional. Dengan kata lain bukti fisik merupakan satu indikator yang paling konkrit yang berupa segala fasilitas nyata yang dapat terlihat. b). Reliability (keandalan); kemampuan untuk memberikan pelayanan yang dijanjikan dengan segera, memuaskan, tepat dan konsisten. c). Responsiveness (daya tanggap); sikap tanggap karyawan dalam memberikan pelayanan yang dibutuhkan pelanggan dan dapat menyelesaikan dengan cepat. Sikap tanggap ini merupakan suatu respon akal dan pikiran yang ditunjukkan pada pelanggan. d). Assurence (jaminan); jaminan adalah upaya perlindungan yang dijanjikan untuk pelanggan terhadap resiko yang apabila resiko itu terjadi akan dapat mengakibatkan masalah yang akan terjadi dikemudian hari. e). Emphaty (empati); empati merupakan individualized attention to customer. Empati adalah perhatian yang dilaksanakan secara pribadi atau individu terhadap pelanggan dengan menempatkan dirinya pada situasi pelanggan.

\section{Kompetensi Karyawan}

Moeherion (2014) mendefiniskan kompetensi sebagai: "A competency is an underlying characteristic of an individual that is causually related of criterian referenced effective and or superrior performance in a job or situation." Yang diartikan Kompetensi sebagai karakteristik yang mendasari individu secara kausal berkaitan dengan kriteria yang direferensikan yang efektif dan atau kinerja dalam pekerjaan atau situasi.

Mangkunegara

mengemukakan bahwa "kompetensi merupakan faktor mendasar yang dimiliki seseorang yang mempunyai kemampuan lebih, yang membuatnya berbeda dengan orang-orang yang mempunyai kemampuan rata-rata atau biasa saja" yang diartikan bahwa kompetensi menjadi factor unik yang melekat pada diri seseorang di luar skil yang membuatnya berbeda pada komunitasnya.

Roe (2001) yang mendefisinikan "competence is defined as the ability to adequately perform a task, duty or role. Competence integrates knowledge, skills, personal values and attitudes. Competence builds on knowledge and skills and is acquired through work experience and learning by doing ". Yang diartikan Kompetensi sebagai kemampuan untuk melaksanakan suatu tugas atau peran, kemampuan mengintegrasikan pengetahuan, ketrampilan-ketrampilan, sikap dan nilai- 
nilai pribadi, dan kompetensi ini muncul dari pengetahuan dan keterampilan yang didasarkan pada pengalaman dan pembelajaran yang dilakukan.

Kravetz (2004) mengatakan "kompetensi adalah sesuatu yang seseorang tunjukan di tempat kerja setiap hari mencakup perilaku, bukan sifat sifat kepribadian atapun keterampilan dasar yang ada didalam maupun di luar tempat kerja" yang diartikan kompetensi adalah kelebihan yang ditonjolkan seorang karyawan dalam kegiatan sehari-hari dalam perusahaan.

Berdasar pada teori-teori tersebut dapat diartikan bahwa kompetensi menggambarkan kemampuan kerja seseorang, dari kompetensi yang dimiliki pada individu, perusahaan dapat mengetahui kemampuan seorang dalam bertanggung jawab, menyelesaikan masalah, dan mentransfer informasi kepada orang lain terkait tugas apa yang sedang diakerjakan. Dapat dikonfirmasi bahwa kompetensi digunakan dalam merencanakan, membantu, dan mengembangkan perilaku dan kinerja seseorang.

Menurut Hutapea dan Thoha (2008) terdapat tiga komponen utama dalam pembentukan kompetensi diantaranya pengetahuan yang dimiliki seseorang, kemampuan, pengalaman, dan perilaku individu. Ketiga komponen tersebut dapat dijelaskan sebagai berikut: a). Pengetahuan (knowlegde); Menurut Kamus Besar Bahasa Indonesia (Pusat Bahasa, 2005) pengetahuan adalah segala sesuatu yang diketahui. "Pengetahuan merupakan hasil dari tahu dan ini terjadi setelah orang melakukan penginderaan terhadap suatu objek tertentu. Sebagian besar pengetahuan diperoleh melalui indera mata dan indera telinga", sedangkan menurut Yuniarsih dan Suwatno (2008) bahwa "pengetahuan sebagai suatu informasi yang dimiliki seseorang khususnya pada bidang spesifik." Yang diartikan pengetahuan pada karyawan sebagai pemahaman pada sebuah sesuatu hal dan atas dasar itu karyawan mengarahkan intuisinya untuk mengkonfirmasi hal tersebut sehingga menentukan berhasil tidaknya pelaksanaan tugas yang dibebankan kepadanya, karyawan yang mempunyai pengetahuan yang cukup akan meningkatkan efisiensi perusahaan. b). Keterampilan (skill); Dalam Kamus Besar Bahasa Indonesia (Pusat Bahasa, 2005), keterampilan adalah kecakapan untuk menyelesaikan tugas. Sehingga dapat disimpulkan bahwa keterampilan atau kemampuan yang terbentuk selama dalam atau saat proses maupun sesudah atapun sebelum melaksanakan tugas yang diemabnya. c). Perilaku (attitude); Menurut Gitosudarmo dan Sudita (2008) mendefinisikan "perilaku kerja sebagai sikap keteraturan perasaan dan pikiran seseorang serta kecenderungan untuk bertindak terhadap aspek lingkungannya."

\section{METODE PENELITIAN}

\section{Populasi dan Sampel}

Populasi adalah kumpulan individu atau objek penelitian yang memiliki karakteristik atau ciri yang di tetapkan (Cooper dan Emory: 2005) dan. Sampel adalah sebagian dari populasi yang memiliki karakteristik yang relatif sama dan dianggap bagian dari observasi yang dipilih dari popolasi dengan menggunakan prosedur tertentu sehingga diharapkan dapat mewakili populasinya.

Populasi yang di gunakan dalam penelitian adalah Nasabah dari PT. Bank Tabungan Negara (Persero).Tbk Kantor Cabang Cibubur yang mengunjungi Bank BTN KC Cibubur dalam waktu 3 hari terakhir pada bulan Januari 2018. Jumlah populasi yang didapat sebanyak 112 orang dengan mencari sampel berjumlah 53 orang digunakan metode nonprobability sampling dengan teknik accidental sampling karena setiap 
anggota populasi tidak memiliki kesempatan atau peluang yang sama sebagai sampel sehingga jika yang bersangkutan adalah nasabah BTN dan dirasa cocok untuk menjadi responden maka dapat dijadikan sampel. Jumlah Pengambilan sampel dalam penelitian ini didasarkan pada formulasi Slovin (Riduwan,2005)

\section{Metode Pengumpulan Data}

Metode pengumpulan data dalam penelitian ini menggunakan kuesioner. Menurut Riduwan (2005:71) kuesioner (angket) adalah daftar pertanyaan yang diberikan kepada orang lain bersedia memberikan respon (responden) sesuai dengan permintaan pengguna. Dalam penelitian ini jenis kuesioner yang digunakan adalah kuesioner tertutup, yaitu Kuesioner yang terdiri atas pertanyaan atau pernyataan dengan sejumlah jawaban tertentu sebagai pilihan. Sedangkan daftar pernyataan dibuat dengan skala Likert yang berisi 5 (lima) tingkatan pilihan jawaban mengenai kesetujuan responden terhadap pernyataan yang dikemukakan.

\section{Uji Kualitas Data}

\section{Uji Validitas}

Uji validitas dilakukan untuk memastikan seberapa baik suatu instrumen digunakan untuk mengukur konsep yang seharusnya diukur. Menurut Sugiyono (2010) untuk menguji validitas dilakukan dengan cara mengkorelasikan antara skor butir pertanyaan dengan skor totalnya.

\section{Uji Reliabilitas}

Arikunto (2006) menyatakan "Reliabilitas menunjuk pada suatu pengertian bahwa sesuatu instrumen cukup dapat dipercaya untuk digunakan sebagai alat pengumpul data karena instrumen tersebut sudah baik".

Kuesioner dikatakan reliabel jika dapat memberikan hasil relatif sama pada saat dilakukan pengukuran kembali pada obyek yang berlainan pada waktu yang berbeda atau memberikan hasil yang tetap.

\section{Teknik Analisis Data}

Suatu penelitian membutuhkan analisis data dan inpterprestasi yang bertujuan menjawab pertanyaanpertanyaan penelitian dalam rangka mengungkapkan fenomena sosial tertentu. Uji asumsi merupakan analisis pengujian sebelum melakukan pengujian hipotesis. Kemungkinan adanya masalah dalam analisis regresi sering terjadi. Penelitian statistik dalam uji analisis data terdiri dari uji asumsi dasar dan uji asumsi yang meliputi : uji normalitas, uji multikolineritas, uji Autokorelasi, dan uji heteroskedasitas.

\section{HASIL PENELITIN DAN PEMBAHASAN}

\section{Uji Validitas Kualitas Layanan}

Dari hasil perhitungan korelasi skor tiap poin pertanyaan Kualitas Layanan dari 53 Responden, dengan jumlah peryataan masing-masing variable 10 pertyataan, Sehingga perhitungan total skor setiap responden diperoleh hasil yang disajikan dalam table berikut: 
Tabel 1. Kualitas Layanan

\begin{tabular}{cccc}
\hline Pernyataan & R Hitung & R Kritis & Kesimpulan \\
\hline Butir 1 & 0.598 & 0.3 & Valid \\
Butir 2 & 0.741 & 0.3 & Valid \\
Butir 3 & 0.747 & 0.3 & Valid \\
Butir 4 & 0.408 & 0.3 & Valid \\
Butir 5 & 0.747 & 0.3 & Valid \\
Butir 6 & 0.282 & 0.3 & Valid \\
Butir 7 & 0.796 & 0.3 & Valid \\
Butir 8 & 0.565 & 0.3 & Valid \\
Butir 9 & 0.663 & 0.3 & Valid \\
Butir 10 & 0.776 & 0.3 & Valid \\
\hline
\end{tabular}

Sumber: Data diolah tahun 2018

Berdasarkan table diatas, dapat dilihat bahwa dari 10 point peryataan semuanya bernilai > 0.3 , dengan demikian maka dapat disimpulkan bahwa semua item masing-masing variable kualitas layanan hasilnya adalah valid.

\section{Uji Validitas Kompetensi Karyawan}

Dari hasil perhitungan korelasi skor tiap poin pertanyaan Kompetensi Karyawan dari 53 Responden, dengan jumlah peryataan masing-masing variable 9 pernyataan, Sehingga perhitungan total skor setiap responden diperoleh hasil yang disajikan dalam table berikut:

Tabel 2. Kompetensi Karyawan

\begin{tabular}{cccc}
\hline Pernyataan & R Hitung & R Kritis & Kesimpulan \\
\hline Butir 1 & 0.739 & 0.3 & Valid \\
Butir 2 & 0.499 & 0.3 & Valid \\
Butir 3 & 0.319 & 0.3 & Valid \\
Butir 4 & 0.739 & 0.3 & Valid \\
Butir 5 & 0.499 & 0.3 & Valid \\
Butir 6 & 0.332 & 0.3 & Valid \\
Butir 7 & 0.739 & 0.3 & Valid \\
Butir 8 & 0.499 & 0.3 & Valid \\
\hline
\end{tabular}

Sumber: Data diolah tahun 2018

Berdasarkan tabel diatas, dapat dilihat bahwa dari 8 point peryataan semuanya bernilai > 0.3 , dengan demikian maka dapat disimpulkan bahwa semua item masing-masing variable Kompetensi Karyawan hasilnya adalah valid.

\section{Uji Validitas Kepuasan Nasabah}

Dari hasil perhitungan korelasi skor tiap poin pertanyaan Kepuasan Nasabah dari 53 Responden, dengan jumlah peryataan masing-masing variable 6 pernyataan, Sehingga perhitungan total skor setiap responden diperoleh hasil yang disajikan dalam table berikut:

Tabel 3. Kepuasan Nasabah

\begin{tabular}{cccc}
\hline Pernyataan & R Hitung & R Kritis & Kesimpulan \\
\hline Butir 1 & 0.572 & 0.3 & Valid \\
Butir 2 & 0.316 & 0.3 & Valid \\
Butir 3 & 0.503 & 0.3 & Valid \\
Butir 4 & 0.593 & 0.3 & Valid \\
Butir 5 & 0.734 & 0.3 & Valid
\end{tabular}




\begin{tabular}{llll} 
Butir 6 & 0.617 & 0.3 & Valid \\
\hline
\end{tabular}

Sumber : Hasil olah data 2018

Berdasarkan table diatas, dapat dilihat bahwa dari 6 point peryataan semuanya bernilai > 0.3 , dengan demikian maka dapat disimpulkan bahwa semua item masing-masing variable Kepuasan Nasabah hasilnya adalah bernilai valid (Rincian dapat dilihat dari Lampiran)

\section{Uji Reabilitas}

Uji reabilitas di maksudkan untuk mengetahui adanya konsistensi alat ukur dalam penggunaanya, atau dengan kata

\begin{abstract}
lain alat ukur tersebut mempunyai hasil yang konsisten apabila di gunakan berkali-kali pada waktu yang berbeda. "Reliabilitas adalah sesuatu instrumen cukup dapat dipercaya untuk digunakan sebagia alat pengumpul data karena instrument tersebut sudah baik" (Arikunto, 2006. Uji reabilitas, dimana suatu instrumen dapat dikatakan handal (reabel) bila memiliki nilai Cronbach Alpha > 0.60 (Ghozali, 2006). Berikut Tabel hasil Uji Reabilitas:
\end{abstract}

\section{Tabel 4. Uji Reabilitas}

\begin{tabular}{lccc}
\hline \multicolumn{1}{c}{ Variabel } & Cronbach Alpha & Nilai kritis $(\alpha)=5 \%$ & Keterangan \\
\hline Kualitas Layanan & 0.755 & 0.600 & Reliabel \\
Kompetensi Karyawan & 0.789 & 0.600 & Reliabel \\
Kepuasan Nasabah & 0.717 & 0.600 & Reliabel \\
\hline
\end{tabular}

Sumber: Hasil pengolahan data primer 2018

Hasil Uji Reliabilitas tersebut menunjukkan semua variabel memiliki nilai ditasa batas yaitu 0.600 , variabel yang dimaksud adalah Kualitas Layanan, Kompetensi Karyawan, dan Kepuasan Nasabah, yang masing-masing memiliki nilai $0.755,0.789$, dan 0.717 sehingga dapat dikatakan semua konsep pengukur masing-masing variabel dari kuisioner adalah reliabel. Variable yang dimaksud adalah yaitu kualitas kayanan, kompetensi naryawan dan nepuasan nasabah, sehingga untuk selanjutnya item-item pada masing-masing konsep variabel tersebut layak digunakan sebagai alat ukur berdasarkan angka-angka Cronbach alpha dari tabel diatas.

\section{Uji Asumsi Klasik \\ Uji Normalitas}

Uji normalitas bertujuan untuk menguji apakah dalam model regresi, variabel bebas dan variabel terikat terdistribusikan secara normal atau tidak. Dalam pengujian ini menggunakan analisa Kolmogorov-Smirnov merupakan suatu pengujian normalitas secara univariate untuk menguji keselarasan data masing-masing variabel penelitian, dimana suatu sampel dapat dikatakan berdistribusi normal atau tidak.

Tabel 5. Hasil Pengujian Normalitas

\begin{tabular}{lcll}
\hline \multicolumn{1}{c}{ Variabel } & Sig. & Keputusan H0 & Kesimpulan \\
\hline Kualitas Layanan & 0.222 & H0 diterima & Data berdistribusi normal \\
Kompetensi Karyawan & 0.189 & H0 diterima & Data berdistribusi normal \\
\hline
\end{tabular}


Berdasarkan hasil olah data dapat diihat bahwa pada variable kualitas layanan dan Kompetensi karyawan semuanya berdistribusi normal dengan tingkat signifikansi $>0,05$ dengan masing-masing nilai kualitas layanan 0.222 dan kompetensi 0.189 .

\section{Uji Multikolinearitas}

Uji Multikolinearitas bertujuan untuk menunjukkan hubungan langsung

Tabel 6. Hasil Pengujian Multikolineritas

\begin{tabular}{lcccc}
\hline \multicolumn{1}{c}{ Variabel } & VIF & Tolerance & Keputusan H0 & Kesimpulan \\
\hline $\begin{array}{l}\text { Kualitas } \\
\text { Layanan }\end{array}$ & 1.015 & 0.985 & H0 Diterima & tidak ada multikolinearitas \\
\hline $\begin{array}{l}\text { Kompetensi } \\
\text { Karyawan }\end{array}$ & 1.015 & 0.985 & H0 Diterima & tidak ada multikolinearitas \\
\hline \multicolumn{3}{l}{ Sumber: Hasil pengolahan data primer 2018 } & \\
\hline
\end{tabular}

Berdasarkan hasil table SPSS diatas, diketahui bahwa seluruh variabel independen yaitu Kualitas Layanan dan Kompetensi Karyawan, mempunyai nilai VIF $<10$ atau nilai Tolerance > 0,1. Sehingga $\mathrm{H}_{0}$ diterima yang dimana nilai Kualitas layanan 1.015 dan Kompetensi Karyawan 1.015, artinya variabel independen tersebut tidak menunjukkan adanya gejala multicolinearitas (tidak ada (korelasi) yang sangat kuat antara variabel independen. Multikolinearitas terjadi jika nilai Variance Inflation Factor (VIF) lebih besar dari 10 atau nilai Tolerance lebih kecil 0,10 (Hair et. al. 1998).

Berdasarkan hasil pengujian SPSS tersebut, maka dapat disimpulkan berdasarkan tabel berikut:

Tabel 7. Hasil Pengujian Autokorelasi

\begin{tabular}{cccccc}
\hline Model & $\mathrm{R}$ & $\mathrm{R}$ Square & $\begin{array}{c}\text { Adjusted R } \\
\text { Square }\end{array}$ & $\begin{array}{c}\text { Std. Error of the } \\
\text { Estimate }\end{array}$ & $\begin{array}{c}\text { Durbin- } \\
\text { Watson }\end{array}$ \\
\hline 1 & $.784^{\mathrm{a}}$ & 0.615 & 0.599 & 1.793 & 2.315 \\
\hline a. Predictors: (Constant), Competence, Service Quality & & \\
b. Dependent Variable: Customer Satisfaction & &
\end{tabular}

Berdasarkan tabel, didapat nilai dari Durbin-Watson (DW) yaitu sebesar 2,315. Jika di bandingkan dengan table durbin-watson, untuk sampel berjumlah 53 dan 2 variabel independent, DL 1.479 dan $\mathrm{DU}=1.635$. sehingga dapat di hitung: Nilai DW $=2.315$, Tabel $\mathrm{DU}=1.635$. (DW) 2.315 diantara (DU) 1.635 dan < (4-DU) (4-1.635) 2.365 hubungan yang sangat kuat antara variabel independen dengan variable independen lainnya). Dengan demikian tidak terjadi pelanggaran asumsi multikolinearitas pada model persamaan regresi.

\section{Uji Autokorelasi}

Uji autokorelasi dilakukan dengan menghitung nilai Durbin-Watson $d$ statistic.
Maka keputusan yang diambil adalah $\mathrm{H} 1$ ditolak, dengan kata lain tidak ada autokorelasi (H0 diterima).

\section{Uji Heterokedestias}

Uji Heteroskedastisitas dilakukan dengan menggunakan uji Glejse, dimana nilai absolut residual diregresikan pada setiap variabel independent. Model regresi yang baik seharusnya tidak terjadi Heteroskedastisitas.

Tabel 8. Hasil Pengujian Heterokedestias 


\begin{tabular}{|c|c|c|c|c|c|c|}
\hline \multirow[t]{2}{*}{ Mode } & & \multicolumn{2}{|c|}{$\begin{array}{l}\text { Unstandardized } \\
\text { Coefficients }\end{array}$} & \multirow{2}{*}{$\begin{array}{c}\text { Standardized } \\
\text { Coefficients } \\
\text { Beta }\end{array}$} & \multirow[t]{2}{*}{$\mathrm{t}$} & \multirow[t]{2}{*}{ Sig. } \\
\hline & & B & Std. Error & & & \\
\hline \multirow{3}{*}{1} & (Constant) & 0.877 & 1.925 & & 0.455 & 0.651 \\
\hline & $\begin{array}{l}\text { Service } \\
\text { Quality }\end{array}$ & 0.039 & 0.033 & 0.167 & 1.195 & 0.238 \\
\hline & Competence & -0.031 & 0.046 & -0.095 & $0.678^{-}$ & 0.501 \\
\hline
\end{tabular}

Sumber: Hasil pengolahan data primer 2018

Berdaasarkan table 8, dapat diketahui bahwa nilai signifikans uji $\mathrm{t}$ antara variabel kualitas layanan dan kompetensi karyawan dengan absolut residual memiliki nilai signifikansi lebih dari 0,05 yaitu, kualitas layanan sebesar 0.238 dan Kompetensi karyawan sebesar 0.501 artinya tidak terjadi Heteroskedastisitas, sehingga dapat disimpulan bahwa Ho ditolak. Dapat dikatakan, variabel-variabel tersebut tidak terdapat heteroskedastisitas.

\section{Analisa Regresi}

Pengujian regresi berganda, meliputi uji simultan (uji F), koefesen determinasi (R2) dan uji partial (uji t).

Tabel 9. Hasil Uji T

\begin{tabular}{|c|c|c|c|c|c|c|c|c|}
\hline \multirow{2}{*}{\multicolumn{2}{|c|}{ Model }} & \multicolumn{2}{|c|}{$\begin{array}{l}\text { Unstandardized } \\
\text { Coefficients }\end{array}$} & \multirow{2}{*}{$\begin{array}{c}\text { Standardized } \\
\text { Coefficients } \\
\text { Beta }\end{array}$} & \multirow{2}{*}{$\mathrm{T}$} & \multirow{2}{*}{ Sig. } & \multicolumn{2}{|c|}{$\begin{array}{l}\text { Collinearity } \\
\text { Statistics }\end{array}$} \\
\hline & & B & $\begin{array}{l}\text { Std. } \\
\text { Error }\end{array}$ & & & & Tolerance & VIF \\
\hline \multirow{3}{*}{1} & (Constant) & -6.782 & 3.583 & & $1.893^{-}$ & 0.064 & & \\
\hline & $\begin{array}{l}\text { Service } \\
\text { Quality }\end{array}$ & 0.448 & 0.061 & 0.651 & 7.357 & 0 & 0.985 & 1.015 \\
\hline & $\begin{array}{l}\text { Competence } \\
\text { Dependent Val }\end{array}$ & $\begin{array}{l}0.353 \\
\text { le: Cus }\end{array}$ & $\begin{array}{c}0.086 \\
\text { mer Sati }\end{array}$ & iction $\quad 0.364$ & 4.115 & 0 & 0.985 & 1.015 \\
\hline
\end{tabular}

Dengan melihat output diatas, terdapat dua hipotesis $(\mathrm{Ha})$ yang diajukan dalam uji t ini: a). $\mathrm{H} 1$ = kualitas layanan (service quality) berpengaruh signifikan terhadap kepuasan nasabah (Y). b). $\mathrm{H} 2=$ kompetensi karyawan (competence) berpengaruh signifikan terhadap kepuasan nasabah.

Berdasarkan table 9, diketahui bahwa nilai koefesien regresi variabel kualitas layanan $\left(\mathrm{X}_{1}\right)$ adalah sebesar

7.357 bernilai positi (+) dan kompetensi karyawan sebesar $\left(\mathrm{X}_{2}\right) 4.115$ bernilai positif (+) dapat dikatakan kualitas layanan dan kompetensi karyawan berpengaruh positif terhadap kepuasan nasabah, sehingga jika semakin meningkat kualitas layanan dan Kompetensi Karyawan yang profesional akan meningkat pula kepuasan nasabah.

Untuk mengetahui pengaruh tersebut signifikan atau tidak maka kedua variable akan kembali diuji hipotesis: 


\section{Uji t Hubungan kualitas layanan terhadap kepuasan nasabah:}

Berdasarkan analisa regresi diperoleh $\mathrm{t}$ hitung sebesar $7.357>\mathrm{t}$ table 2.008 dan nilai signifikansi (Sig.) $0.000<$ 0.05, maka dapat disimpulkan "H0 ditolak dan $\mathrm{H} 1$ diterima yang berarti kualitas layanan berpengaruh signifikan terhadap kepuasan nasabah"

\section{Uji t Hubungan kompetensi karyawan terhadap kepuasan nasabah:}

Hasil dan Pengambilan keputusan dalam Uji t: diperoleh $\mathrm{t}$ hitung sebesar signifikansi (Sig.) $0.000<0.05$, maka dapat disimpulkan $\mathrm{H}_{0}$ tolak dan $\mathrm{H}_{2}$ diterima yang berarti Kompetensi karyawan berpengaruh signifikan terhadap kepuasan nasabah.

\section{Uji F (ANOVA) Simultan}

Uji $\mathrm{F}$ digunakan untuk mengetahui apakah variabel independen yang meliputi independensi kualitas layanan dan kompetensi karyawan secara bersama-sama (simultan) berpengaruh terhadap variabel dependen yaitu kepuasan nasabah.

\section{$4.115>\mathrm{t}$ table 2.008 dan nilai}

Tabel 10. Hasil Uji F

\begin{tabular}{|c|c|c|c|c|c|c|}
\hline \multicolumn{2}{|c|}{ Model } & Sum of Squares & $\mathrm{df}$ & $\begin{array}{c}\text { Mean } \\
\text { Square }\end{array}$ & $\mathrm{F}$ & Sig. \\
\hline \multirow{3}{*}{1} & Regression & 256.266 & 2 & 128.133 & 39.854 & $.000^{\mathrm{b}}$ \\
\hline & Residual & 160.753 & 50 & 3.215 & & \\
\hline & Total & 417.019 & 52 & & & \\
\hline
\end{tabular}

a. Dependent Variable: Customer Satisfaction

b. Predictors: (Constant), Competence, Service Quality

Sumber: Hasil pengolahan data primer 2018

Berdasarkan tabel, yang merupakan hasil uji $\mathrm{F}$ (uji simultan), diketahui $\mathrm{F}$ hitung 39.854 dengan taraf signifikansi $0,000 \quad(<0,05)$. Dari hasil pengujian tersebut maka dapt disimpulkn bahwa variabel independent (kualitas layanan dan kompetensi karyawan) secara bersamasama mempengaruhi (secara simultan) variabel dependennya yaitu Kepuasan Nasabah.

\section{Koefesien Determinasi (R2)}

Koefisien determinasi merupakan besaran yang menunjukkan besarnya variasi variabel dependen yang dapat dijelaskan oleh variabel independennya, koefisien deteminasi ini digunakan untuk mengukur seberapa jauh variabel-variabel bebas dalam menerangkan variabelvariabel terikatnya. Nilai koefisien determinasi ditentukan dengan nilai $\mathrm{R}$ square, sebagaimana dapat dilihat pada tabel 11i:

\section{Tabel 11. Hasil Uji F}

\begin{tabular}{rrrrrr}
\hline Model & \multicolumn{1}{l}{ R } & R Square & $\begin{array}{c}\text { Adjusted R } \\
\text { Square }\end{array}$ & $\begin{array}{c}\text { Std. Error of } \\
\text { the Estimate }\end{array}$ & $\begin{array}{c}\text { Durbin- } \\
\text { Watson }\end{array}$ \\
\hline 1 & $.784^{\mathrm{a}}$ & 0.615 & 0.599 & 1.793 & 2.315 \\
\hline
\end{tabular}

a. Predictors: (Constant), Competence, Service Quality

$b$. Dependent Variable: Customer Satisfaction

Sumber: Hasil pengolahan data primer 2018

Dari hasil penelitian, dapat diketahui bahwa koefisien determinasinya $\left(\mathrm{R}^{2}\right)$ diperoleh nilai sebesar 0.615 atau sama dengan $61.5 \%$, angka ini mengandu arti bahwa konstribusi variabel kualitas layanan dan kompetensi karyawan berpengaruh terhadap kepuasan nasabah sebesar $61.5 \%$, sedangkan, sisanya sebesar 
$38.5 \%$, disumbangkan oleh variabel lain yang tidak diajukan dalam penelitian ini.

\section{Pembahasan}

\section{Pengaruh kompetensi karyawan dan kompetensi karyawan terhadap kepuasan nasabah \\ Berdasarkan hasil, Secara simultan} variabel kualitas layanan dan kompetensi karyawan secara bersama-sama berpengaruh signifikan terhadap kepuasan nasabah, yang ditunjukkan dengan $\mathrm{F}$ hitung 39.854 dengan taraf signifikansi $0,000 \quad(<0,05)$. Hasil ini membuktikan bahwa kebenaran teori dari Tjiptono (2014) yang menyebutkan "kepuasan pelanggan merupakan respon emosional terhadap pengalamanpengalaman berkaitan dengan produk atau jasa tertentu" yang dibeli, pola perilaku (seperti perilaku berbelanja dan perilaku pembeli) serta pasar secara keseluruhan" berdasakan penjelasan diatas menunjukan meski nilai kualitas layanan dan kompetensi dari karyawan berbeda, namun keduanya mempunyai pengaruh positif dan signifikan terhadap kepuasan nasabah, kualitas layanan dan kompetensi karyawan sanggup memuaskan nasabah diluar dari variabel lain yang tidak diikut sertakan dalam penelitian ini. Hal ini menjukan bahwa kualitas layanan dan komptensi karyawan telah menjadi dua faktor penting pemberi kepuasan nasabah, sehingga dengan demikian membuktikan hipotesis adanya pengaruh kualitas layanan dan kompetensi karyawan terhadap kepuasan nasabah Bank BTN Cibubur. Berdasarkan hasil analisis penelitian tentaang kualitas layanan dan kompetensi karyawan terhadap kepuasana nasabah PT. bank BTN KC Cibubur, di peroleh hasil dari perhitungan koefesen determinasi bahwa kedua variable independen berpengaruh signifikan terhadap kepuasan nasabah. Besaran pengaruh kedua variable terhadap kepuasan sebesar 61.5\%, melihat besarnya pengaruh kedua variabel yaitu kualitas layanan dan kompetensi karyawan sudah sepatutnya menjadi perhatian khusus bagi perusahaan perbankan dalam rangka peningkatan layanan dan kompetensi karyawan berbasis kepuasan terhadap nasabah namun variable lain yang bernilai sebesar $38.5 \%$ yang tidak ikut diteliti juga perlu mendapat perhatian dalam rangka penyempurnaan kinerja perbankan

\section{Pengaruh kualitas layanan terhadap kepuasan nasabah}

Hasil perhitungan variabel hubungan kualitas layanan terhadap Kepuasan nasabah Diperoleh hasil uji $t$ hitung sebesar $7.357>\mathrm{t}$ table 2.008 dan nilai signifikansi (Sig.) $0.000<0.05$, hal ini dapat diartikan secara parsial Kualitas layanan memiliki pengaruh yang signifikan terhadap kepuasan nasabah dan menunjukan hubungan yang positif diantara keduanya. Hasil penelitian ini sesuai degan teori dari Kotler (2000) yang mengemukakan, "kualitas pelayanan merupakan totalitas dari bentuk karakteristik barang dan jasa yang menunjukkan kemampuannya untuk memuaskan kebutuhan pelanggan, baik yang nampak jelas maupun yang tersembunyi". Juga memperkuat penelitian terdahulu dari Tombokan, et, al (2015) yang melakukan penelitian di Bank BNI, dengan demikian penelitian ini telah membuktikan hipotesis adanya pengaruh kualitas layanan terhadap kepuasan nasabah Bank BTN Cibubur.

Sehingga dapat dikatakan jika perusahan perbankan terus memperhatikan dan memperbaiki kualitas layanan, maka kepuasan nasabah akan bertambah besar, dengan demikian nasabah tidak akan lagi memiliki keraguan dalam mempercayakan 
uangnya, fasilitas unggulan dan kenyamanan serta keramahan akan membuat nasabah seakan di layani sepenuh hati.

\section{Pengaruh kompetensi karyawan terhadap kepuasan nasabah}

Hasil perhitungan variabel kompetensi karyawan terhadap kepuasan nasabah di peroleh hasil uji $t$ hitung sebesar $4.115<\mathrm{t}$ table 2.008 dan nilai signifikansi (Sig.) $0.000>0.05$, dapat dikatakan kompetensi karyawan secara parsial berpengaruh signifikan terhadap kepuasan nasabah dan menunjukan hubungan yang positif antar kedua variabel. Penelitian ini membuktikan teori dari Mangkunegara (2005) yang mengemukakan bahwa "kompetensi merupakan faktor mendasar yang dimiliki seseorang yang mempunyai kemampuan lebih, yang membuatnya berbeda dengan seseorang yang mempunyai kemampuan rata-rata atau biasa saja" yang dapat diartikan bahwa kompetensi menjadi faktor unik yang melekat pada diri seseorang yang membuatnya spesial dan diperhitungkan oleh nasabah. Dan mendukung penelitian terdahulu yang dilakukan oleh Yonathan dengan demikian membuktikan hopitesis Adanya pengaruh Kompentensi terhadap kepuasan Nasabah Bank BTN Cibubur. Kompetensi karyawan merupakan modal utama karyawan dalam menghadapi nasabah. Keunggulan SDM ini akan menjadi harga jual dalam menentukan kepuasan nasabah, jelas nasabah mengaharapkan layanan terbaik dari perusahaan perbankan dari karyawan yang kompeten, harapan akan kepuasan ini akan terbayar dengan hadirnya karyawan yang memikiki skill komunikasi yang baik, sikap yang ramah dan wawasan yang luas, sehingga kompetensi karyawan juga selayaknya menjadi perhatian serius perusahaan perbankan dalam menempatkan atapun merekrut karyawan dalam posisi yang tepat, sesuai dengan pepatah Ada pepatah: "the right man in the right job, the right job in the right man". Artinya, orang yang tepat harus pada posisi, tugas atau pekerjaan yang tepat. Pekerjaan dan tugas yang tepat, juga harus ditangani orang yang tepat.

\section{KESIMPULAN DAN SARAN}

\section{Kesimpulan}

Berdasarkan bahasan di atas simpulannya adalah 1). Secara simultan kualitas layanan dan kompetensi karyawan berpengaruh signifikan dan positif terhadap kepuasan nasabah PT. Bank BTN KC Cibubur, artinya perusahaan perbankan harus memberikan pelayanan dan penempatan sumber daya manusia yang kompeten diposisi yang tepat, jika hal ini tercapai maka kepuasan nasabah akan meningkat. 2). Secara parsial kualitas layanan berpengaruh signifikan dan positif terhadap Kepuasan nasabah, hal ini menjukan bahwa kualitas layanan menjadi pertimbangan utama nasabah dalam menjalin hubungan dengan perbankan, jika kualitas layanan ditingkatkan dan terus diperbaiki maka kepuasan nasabah pada PT. Bank BTN KC Cibubur akan meningkat. 3). Secara parsial kompetensi karyawan berpengaruh signifikan dan positif terhadap kepuasan nasabah. Kompetensi karyawan juga menjadi faktor pendukung kepuasan nasabah dalam berinteraksi dengan bank, petimbangan atas kompetensi karyawan bank menjadikan nasabah percaya dengan bank tersebut, karena apapun masalah yang dihadapi oleh nasabah, nasabah beranggapan harus mendapatkan informasi yang pasti dan meyakinkan sehingga akan tercipta rasa ketanangan, keyakinan, kepercayaan dan kepuasan yang dimaksudkan. Jika kompetensi ini terus mendapat perhatian dan perbaikan dari perusahaan perbankan, maka kepuasan nasabah dipastikan akan meningkat. 


\section{Saran}

Berdasarkan kesimpulan diatas, maka dapat disarankan dan menjadi bahan pertimbangan serta masukan yang diharapkan dapat berguna bagi Bank Tabungan Negara KC Cibubur. Saran dan rekomendasikan adalah sebagai berikut: 1). Disarankan Bank BTN KC Cibubur tetap memberikan peningkatan terhadap kualitas layanan dengan memperhatikan aspek-aspek layanan yang berkualitas, dimbangi dengan penempatan SDM yang kompeten di bidangnya, dengan begitu harapan nasabah akan terpuaskan. 2). Disarankan perlunya perbaikan dan inovasi sistem jaringan informasi baik penyediaan Mesin ATM, memperluas jangkauan cabang, perluasan jaringan perbankan, dan meningkatkan kinerja sistem layanan berbasis internet seperti Mobile Banking dan Internet Banking, Serta memberikan Promo, Undian, kemudahan betransaksi dan yang terpenting adalah memperhatikan How to Customer Satisfaction.

\section{DAFTAR PUSTAKA}

Alma, Buchari. 2013. Manajemen Pemasaran dan Pemasaran Jasa. Bandung, Alfabeta.

Anderson,N. Ones D.S, Sinangil, H.K dan Viswesvaran, C. 2005. Handbook Of Industrial, work, and organizational Psychology. Vol 01. London. Sage

Anwar Prabu Mangkunegara, 2002, Manajemen Sumber Daya Manusia, Bandung PT. Remaja Rosda Karya. Anwar Prabu Mangkunegara. 2005. Sumber Daya Manusia perusahaan. Bandung. PT.Remaja Rosdakarya.

Arikunto, Suharsimi. 2006. Prosedur Penelitian Suatu Pendekatan Praktik. Jakarta. Rineka Cipta.

Basu Swasta, Dharmesta dan Irawan, 2008, Manajemen Pemasaran. Modern, Liberty, Yogyakarta.
Basu, Swastha DH., Irawan. 2008. Manajemen Pemasaran Modern, Edisi Kedua, Cetakan Ke-tigabelas, Yogyakarta: Liberty Offset,

Becker Brian E, Hunselid Mark A, Ulrich Dave. 2001," The HR Scorecard : Linking People, Strategy and Performance", Harvard Business School Press, Boston, Massachucetts.

Cooper dan Emory, 205, Metode Penelitian Bisnis, Jakarta:Erlangga

Finnora, E and Razak, I., 2010. Pengaruh kualitas layanan dan citra perusahaan terhadap kepuasan nasabah. Jurnal manajemen bisnis krisnadwipayana. 5(2).2017.

Ghozali, Imam. 2005. Aplikasi Analisis Multivariate dengan program SPSS. Semarang Universitas Diponegoro..

Ghozali, Imam. 2009. Aplikasi Analisis Multivariate Dengan Program SPSS. Edisi keempat. Semarang. Universitas Diponegoro.

Ghozali, Imam. 2012. Aplikasi Analisis Multivariate dengan program IBM SPSS, Edisi keenam. . Semarang. Universitas Diponegoro

Gitosudarmo, Indriyo dan I Nyoman Sudita. 2008. Perilaku Keorganisasian. Yogyakarta : BPFE.

Goetsch, D., \& Davis, S. B. (2002). Manajemen Mutu Total, Manajemen Mutu untuk Produksi, Pengolahan dan Pelayanan. Jakarta. Prenhallindo

Harahap, A. R., Ruslan, D.,and Fitrawaty (2017), The Influence of Service Quality on Customer Satisfaction and Loyalty of Muamalat Bank Branches Tanjung Balai. Journal of Business and Management Sciences. 5. 72-76

Hardiansyah .2011. Kualitas Pelayanan Publik. Yogyakarta. Gava Media.

Horsu, E. N and Yeboah, S.T (2015). Influence of service quality on 
customer satisfaction: a study of minicab taxi services in cape coast, Ghana. International Journal of Economics, Commerce and Management. 3. 1451-1464

Hutapea, Parulian dan Nurianna Thoha, 2008, Kompetensi Komunikasi Plus : Teori, Desai, Kasus, dan Penerapan untuk HR dan Organisasi yang dinamis, Jakarta. Gramedia Pustaka Utama,

Hutapea, Thoha. 2008. Kompetensi Plus. Jakarta. PT Gramedia Pustaka Utama

Isnaini, M., Kusuma, D. W. and Noviani, L., (2005) pengaruh kompetensi dosen dan fasilitas belajar terhadap kepuasan mahasiswa pendidikan ekonomi FKIP UNS. Print

Kotler, Philip 2005, Manajemen Pemasaran, Jilid I dan II, Jakarta PT. Indeks,

Kotler, Philip, (2000), Manajemen Pemasaran, Jakarta. PT. Prenhallindo,

Kotler, Philip, 2002, Manajemen Pemasaran, Jilid 1, Edisi Milenium, Jakarta,

Kravetz. 2004. Human Resource Management. Boston . McGrawHill,

Long, C. S., Ibrahim,Z., and Kowang, T .O., (2014). An Analysis on the Relationship between Lecturers' Competencies and Students' Satisfaction. International Education Studies. 7 (1). 37-46

Lovelock, Christoper dan Jochen Writz. 2011. Service Marketing. New Jersey. USA. Pearson

Lovelock, Christoper dan Lauren Wright. 2005. Principles of Service Marketing and Management. Second Edition. New Jersey. USA. Pearson

Malik, M, E., Ghafoor, M. M., and Iqbal, H. K., (2012). Impact of Brand Image, Service Quality and price on customer satisfaction in Pakistan
Telecommunication sector. International Journal of Business and Social Science. 3(23). 123-129

Manghesa, A.H., 2015. Effects of marketing competency of frontline employees on customer satisfaction: A study on commercial bank of Ethiopia. Journal of Business Management. 1(4). 39-50

Mathis, R.L. \& J.H. Jackson. 2006. Human Resource Management: Manajemen Sumber Daya Manusia. Terjemahan Dian Angelia. Jakarta: Salemba Empat

Meriana, Linda., Agung, G.P. M., and Tarigan, Z.J.H., (2014). Analisa dampak kompetensi karyawan terhadap kepuasan konsumen melalui kualitas produk dan kualitas layanan di hachi hachi bistro Surabaya. Jurnal. 479-495

Miller, Rankin and Neathey, 2001, Competency Framerworks in UK Organization, London. CIPD.

Moeherion, 2014. Pengukuran Kinerja Berbasis Kompetensi, Edisi Revisi, Jakarta, Rajawali Pers

Nugroho, Agung. 2005. Strategi Jitu Memilih Metode Statistik Penelitian dengan SPSS. Jogyakarta . Andi.

Prehallindo.

Prihadi, Syaiful F. 2004. Assesment Centre, Identifikasi pengukuran dan pengembangan pribadi. Jakarta PT Gramedia Pustaka Utama, I

Pusat Bahasa Depdiknas, 2005, Kamus Besar Bahasa Indonesia, Jakarta. Balai Pustaka,

Riduwan. 2005. Skala Pengukuran Variabel-variabel Penelitian. Bandung. CV Alfabeta.

Ridwinsyah, Oky. (2017). Pengaruh kompetensi sumber daya insani terhadap tingkat kepuasan nasabah pembiayaan murabahah (Studi pada PT. BPRS Mitra Agro Usaha Kota Bandar Lampung). Skripsi. Perbankan Syariah fakultas ekonomi dan bisnis Islam Print 
Robert, AB., and Wowor, Cindy P. (2005). The influence of service quality on customer satisfaction and service (empirical study at celebrity fitness Jakarta). 3(2). 154175.

Roe, Robert A. 2001. Trust Implication for performance and effectivenesss, European Jurnal.

Sarwono, Jhonatan. 2006. Metode Penelitian Kuantitatif dan Kualitatif. Yogyakarta. Graha Ilmu.

Sarwono, Jhonatan. 2012. Metode Penelitian Bisnis. Bandung. Alfabeta

Siregar, Syofian. 2012. Metode Penelitian Bisnis. Bandung Alfabeta.

Siregar, Syofian. 2013. Metode Penelitian Kuantitatif. Jakarta: PT Fajar Interpratama Mandiri.

Sugiyono 2010, Metode Penelitian Kuantitatif kualitatif dan RND, Bandung, Alfabeta

Tombokan, F., Kawet, L., Uhing., Y., 2015. Pengaruh kualitas pelayanan, citra merek terhadap kepuasan konsumen pengguna taplus bni kantor cabang utama Manado. Jurnal emba: jurnal riset ekonomi, manajemen, bisnis dan akuntansi. 3(3). 552-561

Wibowo. 2007. Manajemen Kinerja. Jakarta: PT Raja Grafindo Persada

Wijaya Tony, 2011. Manajemen Kualitas Jasa, Jakarta :PTIndeks

Yonathan, Ivana C. (2013). Pengaruh kompetensi, informasi, karyawan dan bukti fisik terhadap kepuasan dan loyalitas konsumen pada zangrandi di Surabaya. Print

Yunarsih, Tjutju, dan Suwatno 2008. Manajemen sumber daya manusia. Bandung. Alfabeta

Zeithaml. Valarie, Bitner \& Gremler. 2009 Services Marketing Integrating Customer Focus Across the Firm. New York: McGraw Hill. 